\title{
Expression of the Murine Plasma Cell Nucleotide Pyrophosphohydrolase PC-1 Is Shared by Human Liver, Bone, and Cartilage Cells Regulation of PC-1 Expression in Osteosarcoma Cells by Transforming Growth Factor- $\beta$
}

\author{
Raymond Huang, * Michael Rosenbach, * Richard Vaughn, * Diego Provvedini, * Neil Rebbe, Scot Hickman, \\ James Goding, 8 and Robert Terkeltaub* \\ * San Diego Veterans Affairs Medical Center, University of California San Diego School of Medicine, La Jolla, California 92161; \\ ${ }^{\ddagger}$ John Cochran Veterans Affairs Hospital and Washington University Medical Service, St. Louis, Missouri 63106; and ${ }^{\S}$ Department of \\ Pathology and Immunology, Monash Medical School, Prahran, Australia 3181
}

\begin{abstract}
A bone and cartilage enzyme with both 5 '-nucleotide phosphodiesterase I and nucleotide pyrophosphohydrolase (NTPPPH) activity modulates physiologic mineralization and pathologic chondrocalcinosis by generating inorganic pyrophosphate. We hypothesized that, as for alkaline phosphatase, expression of an NTPPPH gene can be shared by cells from bone, cartilage, and liver and by certain leukocytes.

Recently, we demonstrated the hepatocyte and murine plasma cell membrane glycoprotein PC-1 to have both 5 'nucleotide phosphodiesterase I and NTPPPH activity. We detected polypeptides cross-reactive with PC-1 in human U20S osteosarcoma cells, articular chondrocytes, homogenized human knee cartilages, human knee synovial fluids, hepatoma cells, and murine plasmacytoma cells. Constitutive low abundance PC-1 mRNA expression was detected in U20S cells and chondrocytes by a nested RNA-PCR assay and by Northern blotting. TGF $\beta$ is known to substantially increase NTPPPH activity in primary osteoblast cultures. We demonstrated that TGF $\beta 1$ increased NTPPPH activity and the level of PC-1 mRNA and immunoprecipitable $\left[{ }^{35} \mathrm{~S}\right]$ methionine-labeled $\mathrm{PC}-1$ polypeptides in U20S cells.

The identification of PC-1 as an NTPPPH expressed in cells derived from bone and cartilage may prove useful in furthering the understanding of the role of NTPPPH in physiologic and pathologic mineralization. (J. Clin. Invest. 1994. 94:560-567.) Key words: PC-1 • nucleoside triphosphate pyrophosphohydrolase $\cdot$ bone mineralization $\bullet$ chondrocalcinosis $\bullet$ transforming growth factor- $\beta$
\end{abstract}

\section{Introduction}

Membrane-bound enzyme activity that hydrolyzes the nucleoside monophosphate-pyrophosphate (phosphodiester I) bond in

This work was partially presented in abstract form at the 1993 National Meeting of the American College of Rheumatology in San Antonio, TX on 10 November 1993

Address correspondence to Robert A. Terkeltaub, M.D., Rheumatology Section, San Diego Veterans Affairs Medical Center, 111 K, 3350 La Jolla Village Drive, San Diego, CA 92161.

Received for publication 12 May 1993 and in revised form 6 April 1994.

The Journal of Clinical Investigation, Inc.

Volume 94, August 1994, 560-567 nucleotides (termed nucleotide pyrophosphohydrolase, abbreviated NTPPPH $)^{1}$ is expressed by osteoblasts, chondrocytes, and many other tissues (e.g., placenta, erythrocytes, fibroblasts, and hepatocytes [1-4]). NTPPPH participates in a cascade system of enzymes that hydrolyze nucleotides and nucleic acids to nucleosides (5). This enzyme chain permits the salvage of nucleotides from extracellular fluids such as bile (5) and the uptake of nucleosides by cells that do not rely on synthesis of purines by the de novo pathway $(6,7)$. Furthermore, scavenging of extracellular ATP released by injured and dividing cells may be necessary to prevent tissue injury triggered by ATP-induced cellular activation (8).

In bone and cartilage, NTPPPH-catalyzed release of inorganic pyrophosphate ( $\mathrm{PPi}$ ) from nucleoside triphosphates provides a substrate for alkaline phosphatase-catalyzed generation of $\mathrm{Pi}$ and the crystallization of basic calcium phosphates (913). The role of NTPPPH activity in physiologic endochondral mineralization is reinforced by the presence of NTPPPH in growth plate cartilage matrix vesicles (11-15). NTPPPH activity is also linked to pathologic mineralization of adult hyaline articular cartilage, i.e., deposition of crystals of hydroxyapatite and other basic calcium phosphates (16), and of calcium pyrophosphate dihydrate (CPPD) (in CPPD crystal deposition disease, or chondrocalcinosis) (17-20). Specifically, adult cartilage, like osteoblasts and growth plate cartilage, contains matrix vesicles $(21,22)$, and the addition of an exogenous NTPPPH substrate (ATP) (23) to purified human adult cartilage matrix vesicles and to cartilage promotes the generation of CPPD-like crystals at physiologic $\mathrm{pH}(22,24)$.

Bone, cartilage, and other tissue NTPPPH enzymes (1-4, $9,10,25-27$ ) share the capacity to recognize and hydrolyze the phosphodiester I bond in a variety of nucleotides and synthetic nucleoside substrates (e.g., nucleotide sugars, 3'-phosphoadenosine 5'-phosphosulfate), are "ectoenzymes"' (i.e., functionally active on the extracellular face of the plasma membrane), and have an alkaline $\mathrm{pH}$ optimum.

The genes responsible for human bone and cartilage enzymes with NTPPPH activity are unknown. Importantly, one gene for another ectoenzyme, L/B/K alkaline phosphatase, can be expressed in different forms by hepatocytes, osteoblasts, and chondrocytes and certain granulocytic cells (28). Thus, we hypothesized that, like certain other ectoenzymes, at least one NTPPPH species in osteoblasts and cartilage may be expressed by bone and cartilage cells, liver cells, and also serve as a

1. Abbreviations used in this paper: CPPD, calcium pyrophosphate dihydrate; NTPPPH, nucleotide pyrophosphohydrolase; PC-1, plasma cell membrane glycoprotein-1; PPi, inorganic pyrophosphate. 
marker for the state of differentiation of certain leukocytes (28, $29)$. In this regard, we noted that the $5^{\prime}$-nucleotide phosphodiesterase I, PC-1, which was first recognized as a differentiation marker for murine antibody-secreting cells of B lymphocyte origin (30-34), is also expressed in bovine hepatocytes (35) and that antibodies to PC-1 reacted with an undefined species by immunostaining in murine hyaline cartilage (36). Cloning and functional characterization of PC-1 has been carried out recently by us $(30,32-34,37)$. We have demonstrated that PC-1 is an ectoenzyme that acts intracellularly and extracellularly and functions as a PPi-generating NTPPPH in both the intracellular and extracellular milieus (38). Furthermore, PC-1 can be expressed in at least one soluble extracellular form (39). Therefore, this study tested the hypothesis that cells from human bone and cartilage may share the capacity of hepatocyes and murine plasma cells to express the NTPPPH PC-1.

\section{Methods}

Tissue sources and culture conditions. A human osteosarcoma cell line with known osteoblast-like characteristics (U2OS) (40) was obtained from American Type Culture Collection (Rockville, MD) and maintained in McCoy's 5A medium supplemented with $15 \%$ FCS, $1 \%$ penicillin-streptomycin, and $2 \mathrm{mM}$ glutamine. A human hepatoma (HepG2) cell line also was obtained from the American Type Culture Collection repository. The murine plasmacytoma cell line, NS-1, which spontaneously expresses PC-1, was cultured as described previously by us (34).

Cartilage and chondrocytes. The cartilages described in these experiments were obtained from the femoral condyles and tibial plateaus of osteoarthritis patients at the time of total knee joint replacement. All chondrocytes were first isolated within the laboratory of Dr. Martin Lotz (UCSD) by methods outlined previously in detail $(41,42)$. After removal of blood and tissue debris, and to avoid chondrocyte culture contamination by other articular tissues, the articular surface was scraped gently with a scalpel from which any tissues stuck from the synovial surface or from synovial fluid were removed. Second, cartilage was collected only from noncalcified areas and from soft cartilage. Fibrillated cartilage was not used at all. Cartilage was minced with a scalpel and treated with trypsin $(10 \% \mathrm{vol} / \mathrm{vol})$ for $15 \mathrm{~min}$ in a $37^{\circ} \mathrm{C}$ waterbath. The samples were transferred to DME containing 5\% FBS, penicillin-streptomycin-fungizone, and $2 \mathrm{mg} / \mathrm{ml}$ clostridial collagenase type IV (Sigma Immunochemicals, St. Louis, MO) and digested for 3 $h$ on a gyratory shaker until the tissue fragments were dissolved.

Subcultured cells (passages 1-5) were trypsinized from T175 flasks and plated in 96-well plates at 5,000-20,000 cells/well in DME $1 \%$ FBS. The media were removed, the wells were washed twice with serum-free DME, and culture was continued in DME supplemented with L-glutamine and antibiotics.

Synovial fluids. Human knee synovial fluids were obtained by informed consent during diagnostic or therapeutic procedures in noninflammatory conditions (osteoarthritis, internal derangement). All were nonhemorrhagic, noninflammatory by transparency and viscosity, and free of crystals by polarized light microscopy. All fluids were treated with EDTA (5 mM), PMSF (100 $\mu \mathrm{M})$ and aprotinin $(0.01 \%)$, and testicular hyaluronidase $(100 \mu \mathrm{g} / \mathrm{ml})$ and centrifuged $(6,900 \mathrm{~g}$ for 30 min at $4^{\circ} \mathrm{C}$ ) to remove cells and particulates.

5 '-Nucleotide phosphodiesterase I assay. The assay was performed using as substrate $1 \mathrm{mM} p$-nitrophenyl-thymidine 5 '-monophosphate (PNTM) (Sigma Immunochemicals) in $50 \mathrm{mM}$ Hepes-buffered DME containing $1.6 \mathrm{mM} \mathrm{MgCl}, \mathrm{pH} 8.0$, in a volume of $0.5 \mathrm{ml}$ to which $0.05 \mathrm{ml}$ of sample was added for $1 \mathrm{~h}(10,27)$. The assay was halted by addition of $4 \mathrm{vol}$ of $100 \mathrm{mM} \mathrm{NaOH}$, and absorbance at OD 405 was determined. Specific enzyme activity was measured against a standard curve of $p$-nitrophenol and expressed in Units ( $1 \mathrm{U}$ was equivalent to $1 \mu \mathrm{mol}$ of substrate hydrolyzed per $\mathrm{h}$ ).

Anti-PC-1 antibodies. We used two previously described rabbit polyclonal antisera to recombinant murine PC-1 clones (3-1 and 5) and an antiserum to chromatographically purified, denatured mouse PC-1 (ADPC-1) (34). In addition, two antisera to recombinant human PC1 (R1040 and R1042) were generated by immunizing rabbits with a synthetic peptide consisting of the $\mathrm{COOH}$-terminal 15 amino acids of human PC-1, coupled to bovine serum albumin using glutaraldehyde, and emulsified in complete Freund's adjuvant. A 50\% saturated ammonium sulfate cut was isolated from each anti-human PC-1 antiserum and from control nonimmune rabbit serum and was washed twice by passive adsorption to an equal volume of human erythrocytes before being used.

Western blot detection of PC-1. Lysates of washed cells were generated by treatment for $10 \mathrm{~min}$ in $1 \%$ Triton X-100. SDS-PAGE and Western blotting were performed largely by previously described methods (43). Specifically, electrophoretic transfer of proteins previously separated in an $8 \%$ SDS-polyacrylamide gel to polyvinylidene difluoride was performed at $450 \mathrm{~mA}$ for $90 \mathrm{~min}$ at $4^{\circ} \mathrm{C}$. Blots previously saturated with blocking buffer $(0.25 \%$ powdered nonfat milk, $0.12 \%$ Tween 20 , in SSC) were incubated overnight with anti-PC-1 primary antibody (at 1:2,000 in blocking buffer), washed twice, and incubated with alkaline phosphatase-conjugated goat anti-rabbit IgG (in blocking buffer at 1:2,000) for $1 \mathrm{~h}$. After two more washes, the blot was washed in assay buffer ( $100 \mathrm{mM}$ diethanolamine, $1 \mathrm{mM} \mathrm{MgCl}$, in $\operatorname{ddH}_{2} \mathrm{O}$ ) and then in chemiluminescent enhancing solution (5\% reagent A, FLASH Western Blot System; Stratagene, La Jolla, CA). The blot was then incubated with the kit's chemiluminescent reagent in assay buffer for $10 \mathrm{~min}$ and then exposed to $\mathrm{x}$-ray film for $10-30 \mathrm{~min}$.

Immunoprecipitation of $P C-1$ activity. Cells were spun down and washed in $150 \mathrm{mM} \mathrm{NaCl}, 10 \mathrm{mM}$ Tris ( $\mathrm{pH} \mathrm{7.6)}$ and resuspended for $24 \mathrm{~h}$ at $4^{\circ} \mathrm{C}$ in the same buffer to which $0.1 \%$ Triton X-100 was added. Cell lysates $(40 \mu \mathrm{g}$ protein in a total volume of $0.02 \mathrm{ml})$ were incubated with $0.01 \mathrm{ml}$ of nonimmune rabbit serum or the same volume of antiPC-1 antisera (a combination of $0.002 \mathrm{ml}$ each of R1040, R1042, 3-1, 5, and ADPC-1) overnight at $4^{\circ} \mathrm{C}$. Staph protein A-Sepharose, $0.05 \mathrm{ml}$ of a $50 \%$ suspension, was then added for $2 \mathrm{~h}$ at $4^{\circ} \mathrm{C}$ with constant agitation, then this suspension was sedimented in a Stratagene picofuge (model \#400550) for $30 \mathrm{~s}$. The beads were then washed twice in 1.0 $\mathrm{ml}$ of the Tris/ $\mathrm{NaCl}$ buffer, as above. To the pelleted beads, or the supernatant $(0.05 \mathrm{ml})$, was added $0.5 \mathrm{ml}$ of buffer containing $1 \mathrm{mM}$ PNTM, $15 \mathrm{mM}$ Hepes, and phenol-free DME, pH 7.4, for $1 \mathrm{~h}$.

For $\left[{ }^{35} \mathrm{~S}\right]$ methionine labeling, confluent U2OS cells $\left(\sim 0.5 \times 10^{6}\right.$ cells in $10 \mathrm{ml}$ ) were labeled with $800 \mu \mathrm{Ci}\left[{ }^{35} \mathrm{~S}\right]$ methionine (NEN, Boston, MA) for $6 \mathrm{~h}$ in methionine-free DME (GIBCO BRL, Baltimore, MD) and chased for $24 \mathrm{~h}$ in complete DME medium in the presence or absence of recombinant TGF $\beta(1 \mathrm{ng} / \mathrm{ml})$ for $24 \mathrm{~h}$. Washed, harvested monlayers were lysed in Triton X-100 (1\%) for $1 \mathrm{~h}$ on ice. The cell lysates $(0.5 \mathrm{ml})$ were precleared with protein $\mathrm{G}-$ Sepharose beads $(0.05$ $\mathrm{ml}$ of a $10 \%$ solution) (Zymed Laboratories, Inc., South San Francisco, CA) by a 2-h incubation at $4^{\circ} \mathrm{C}$, followed by centrifugation at $5,000 \mathrm{~g}$ for $30 \mathrm{~s}$. Antibodies $(0.01 \mathrm{ml}$ total as above) were added for $18 \mathrm{~h}$. Proportionate concentrations of nonimmune sera were used as controls. Polypeptides were precipitated after adding $0.1 \mathrm{ml}$ of a $10 \%$ solution for $1.5 \mathrm{~h}$ at $4^{\circ} \mathrm{C}$. Pellets were washed three times in $5 \mathrm{vol}$ PBS, boiled, and then analyzed by SDS-PAGE. After staining with Coomassie blue, the gels were treated with Amplify (Amersham Corp., Arlington Heights, IL) for $1 \mathrm{~h}$, dried, and exposed to Kodak XAR film at $-70^{\circ} \mathrm{C}$ for $4 \mathrm{~h}$.

Detection of PC-1 mRNA. A full-length human PC-1 cDNA hybridization probe in pBluescript SK- was constructed by ligation of two partial cDNA clones from placental libraries (33). Restriction enzyme mapping and sequencing of the extreme $5^{\prime}$ end of the human PC-1 cDNA construct confirmed identity with human PC-1.

For Northern blotting, mRNA was purified using the Pharmacia LKB Biotechnology Inc. (Piscataway, NJ) "quick mRNA prep kit" according to the manufacturer's instructions. Where indicated, total RNA was isolated by a previously described method using guanidinum isothiocyanate (41). Samples were blotted onto nitrocellulose from a $1.2 \%$ agararose/2.2 $\mathrm{M}$ formaldehyde gel by capillary transfer. Hybrid- 


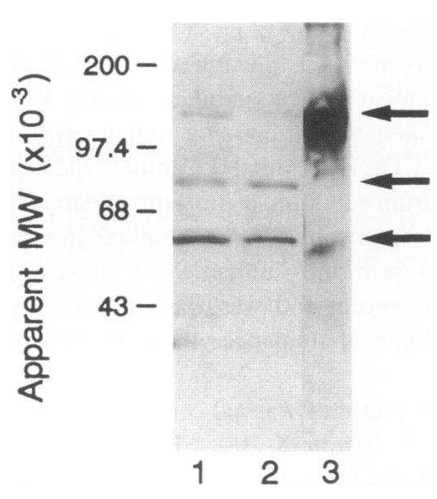

Figure 1. PC-1 polypeptide expression in human hepatoma and osteosarcoma cells and murine plasmacytoma cells. Cell lysates were studied by SDSPAGE and Western blotting, using the anti-PC-1 antiserum, 3-1, as described in Methods. Lane 1, U2OS osteosarcoma cells, $15 \mu \mathrm{g}$; lane 2, HepG2 hepatoma cells, $15 \mu \mathrm{g}$; lane 3 , murine plasmacytoma (NS-1 cells, $25 \mu \mathrm{g}$ ); lane 3 is from a separate gel, for which molecular mass standards are not provided. Molecular mass markers are as indicated on the left. Large arrows identify species of $\sim 130,86$, and $60 \mathrm{kD}$.

ization was to random-primed ${ }^{32} \mathrm{P}$-labeled recombinant human PC-1 (5 $\times 10^{6} \mathrm{cpm} / \mathrm{ml}$ ) at $65^{\circ} \mathrm{C}$ for $16 \mathrm{~h}$. After hybridization, blots were washed twice at $22^{\circ} \mathrm{C}$ for $15 \mathrm{~min}$ in $5 \times \mathrm{SSC}, 0.1 \% \mathrm{SDS}$, and then twice at $65^{\circ} \mathrm{C}$ in $0.5 \times \mathrm{SSC}, 0.1 \%$ SDS for $15 \mathrm{~min}$.

For RNA-PCR, we selected primers that spanned more than one intron (based on knowledge of human PC-1 $5^{\prime}$ intron-exon structure [39]). We prepared a double-stranded cDNA template from $10^{7} \mathrm{U} 2 \mathrm{OS}$ cells by isolating $5 \mu \mathrm{g}$ of total RNA and reverse-transcribing it using random primers and the Invitrogen (San Diego, CA) RT-cDNA PCR kit. One-twentieth of the cDNA was used as a template for two rounds of PCR reaction, using the $5^{\prime}$ and $3^{\prime}$ primers for PC-1 (300 ng each) as indicated below, and $250 \mu \mathrm{M} \mathrm{dNTPs}$, and $2.5 \mathrm{U}$ of AmpliTaq (PerkinElmer/Cetus, Norwalk, CT) in $1.5 \mathrm{mM}$ magnesium containing-buffer (conditions: an initial 4-min run at $94^{\circ} \mathrm{C}$ before starting, then $94^{\circ} \mathrm{C}$ at $2 \mathrm{~min}, 55^{\circ} \mathrm{C}$ at $2 \mathrm{~min}$ for annealing, and $72^{\circ} \mathrm{C}$ at $3 \mathrm{~min}$ for extension. The final extension, at the end of 40 cycles, was for $8 \mathrm{~min}$ at $72^{\circ} \mathrm{C}$ ).

PC-1 RNA-PCR primers were as follows: first round 5' primer: CCA ACA CCT ATA AAG TAC TCT CGC TGG; 3' primer ATC CGG TGA CAA TGC TGT AGT GAT TGG; second round of PCR: 5' primer CCA AGG TAC CTA AAG TAC TCT CGC TGG (starting at base 232 of the coding region of PC-1); 3' primer CTG TGG ATC CTT AAT GCT CTC ACA TGG (starting at base 603 of the coding region).

As a "housekeeping" gene control, we performed a single round of RNA-PCR on the same cDNA templates for the liver ribosomal protein, L30 (44), which we obtained from Dr. Jerrold Olefsky (UCSD). The L30 sense primer was 5'-GAAAGTACGTGCTGGGGTACAAACAGACTC, and the L30 antisense primer was 5'-ATCGGAATCTGGGTCAATGATAGCCAG.

\section{Results}

Osteosarcoma cells and human articular chondrocytes express polypeptides cross-reactive with $P C-1$ in vitro. To test the possibility that PC-1 is expressed by cells of human bone and cartilage, we first compared cell lysates from human chondrocytes, osteosarcoma cells, hepatoma cells, and murine plasmacytoma cells by SDS-PAGE and Western blotting. PC-1 is expressed as a membrane homodimer of $115-130-\mathrm{kD}$ monomers and also as smaller soluble peptides that may be generated via proteolysis (39). PC-1 polypeptides in murine plasmacytoma cells were confirmed $(34,37)$ to be expressed as a predominant full-length species with a molecular mass of $\sim 115-130 \mathrm{kD}$ and as a minor species of $\sim 230,90$, and $60 \mathrm{kD}$ (Fig. 1, lane 3). Osteoblastlike U2OS osteosarcoma cells (40) and a human transformed hepatocyte cell line (HepG2) expressed PC-1 cross-reactive
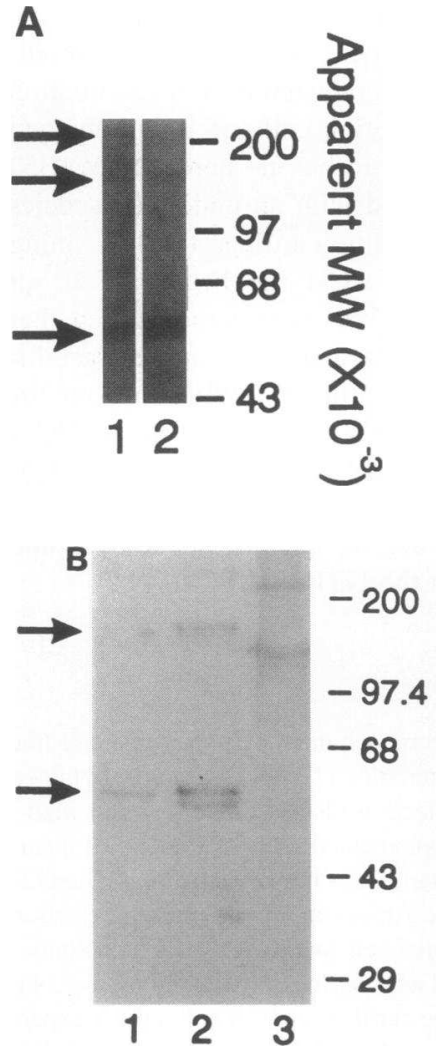

polypeptides that included low abundance species of $\sim 130$ and $86 \mathrm{kD}$ and a higher abundance species of $60 \mathrm{kD}$ (Fig. 1, lanes 1 and 2).

In human articular chondrocytes, antimurine recombinant PC-1 antibodies also detected low abundance polypeptide species with estimated molecular masses of 260,130 , and $60 \mathrm{kD}$ (Fig. 2). In all cells tested, the PC-1 cross-reactive polypeptides of $60 \mathrm{kD}$ became more abundant, and the higher molecular mass species became less abundant as samples were stored for longer periods of time (data not shown), suggesting that the 60-kD species might arise from degradation of parent PC-1 molecules.

Thus, the capacity for PC-1 expression appeared to be shared by murine plasma cells, human hepatoma cells, and human osteosarcoma cells and chondrocytes. PC-1 also was expressed by whole cartilage in the joint space in vivo. Specifically, knee articular cartilage homogenates from osteoarthritis patients contained polypeptides compatible with full-length PC1 species (Fig. 3, lanes 1 and 2). Smaller polypeptides that were cross-reactive with PC-1 were also present in cartilage homogenates (Fig. 3, lanes 1 and 2). Furthermore, in the course of storing cartilage samples, as with the storage of lysates of cultured cells discussed above, we noted that PC-1 cross-reactive polypeptides of $60 \mathrm{kD}$ became more abundant, and larger polypeptides became less plentiful with time (data not shown).

Because articular cells can export products into the synovial fluid, we ascertained whether PC-1 polypeptides were detectable in human synovial fluids. Eight nonhemorrhagic knee synovial fluids (four uncomplicated osteoarthritis, four internal derangements ) all contained $\mathrm{PC}-1$ cross-reactive species, predominantly in the form of a $60-\mathrm{kD}$ polypeptide (Fig. 4). Some PC1 polypeptides from synovial fluids did not enter the gel well 


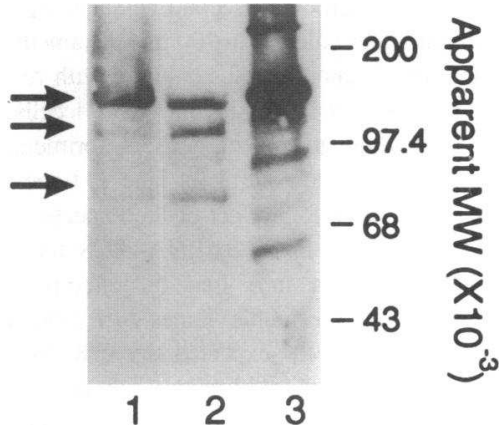

(Fig. 4); the nature of this cross-reactive material was not investigated.

$P C-1$ is constitutively a low abundance mRNA in human chondrocytes and osteosarcoma cells. The active site of PC-1 is highly homologous to that of intestinal alkaline phosphodiesterase $(45,46)$, suggesting that PC- 1 could share a conserved enzymatic domain with related but nonidentical enzymes in other tissues. Therefore, to verify that $\mathrm{PC}-1$ was being expressed in chondrocytes, we attempted to detect transcription of PC-1. PC-1 is expressed as a very low abundance mRNA in certain tissues $(33,47)$. For example, Northern blot hybridization to $10 \mu \mathrm{g}$ of isolated mRNA was previously required to confirm PC-1 mRNA expression in human fibroblasts under resting conditions (47). Under similar conditions (Fig. 5), using $10 \mu \mathrm{g}$ of mRNA, we also detected PC-1 mRNA $(3.8 \mathrm{~kb})$ on Northern blots from human chondrocytes and osteosarcoma cells. However, because of the low strength of the signal, transcription of

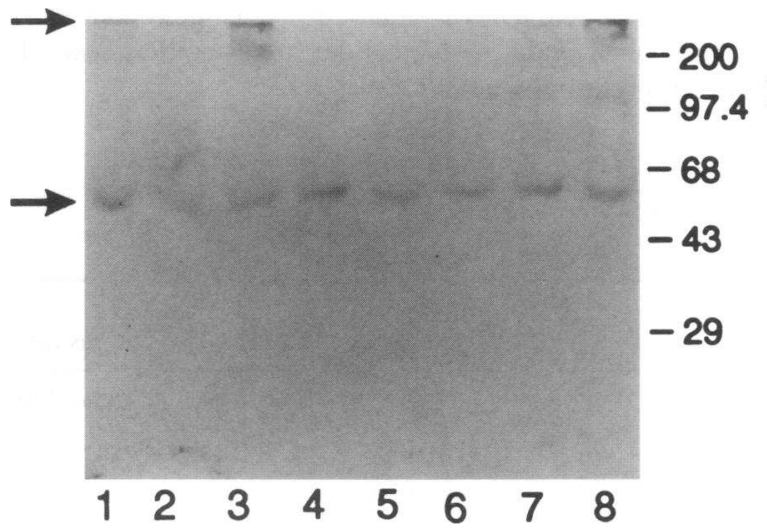

Figure 4. PC-1 cross-reactive polypeptides in human synovial fluids. Grossly noninflammatory synovial fluids ( $25 \mu \mathrm{g}$ of protein) from eight separate patients were isolated and treated as described in Methods and studied by SDS-PAGE and Western blotting using antiserum 3-1 as described above. Lanes $1-4$ were from patients with osteoarthritis; lanes 5-8 were from patients with internal derangements. Arrows indicate polypeptides of $60 \mathrm{kD}$ in all specimens and high molecular mass material that did not enter the gel in specimens $1-3$ and 8 . Faint PC-1 polypeptides of $130 \mathrm{kD}$ were seen in lanes $6-8$ but did not reproduce well in photographs.
Figure 5. Constitutive low abundance PC-1 mRNA in osteosarcoma cells and cultured articular chondrocytes detected by Northern blotting. $10 \mu \mathrm{g}$ of mRNA was purified from U2OS cells (lane 1) and human chondrocytes (lane 2) using the Pharmacia LKB Biotechnology Inc. "Quick mRNA prep kit" according to the manufacturer's instructions. Samples were blotted onto nitrocellulose from a $1.2 \%$ agarose/2.2 $\mathrm{M}$ formaldehyde gel by capillary transfer. Hybridization with random-primed ${ }^{32} \mathrm{P}$-labeled recombinant PC-1 $\left(5 \times 10^{6} \mathrm{cpm} / \mathrm{ml}\right)$ was at $65^{\circ} \mathrm{C}$ for $16 \mathrm{~h}$. After hybridization, blots were washed twice at $22^{\circ} \mathrm{C}$ for $15 \mathrm{~min}$ in 5 $\times$ SSC, $0.1 \%$ SDS, and then twice at $65^{\circ} \mathrm{C}$ in $0.5 \times \mathrm{SSC}, 0.1 \%$ SDS for 15 min. The autoradiograph was exposed for $10 \mathrm{~d}$ at $-70^{\circ} \mathrm{C}$. RNA size standards are indicated on the left. Arrowhead, 3.8 kb PC-1 mRNA, lanes 1 and 2 .

PC-1 was further verified in chondrocytes and osteosarcoma cells via nested RNA-PCR.

To detect PC-1 by RNA-PCR, we selected primers likely to span at least one intron, based on our knowledge of PC-1 5' intron-exon structure (39). Using two rounds of PCR, with nested primers, we amplified PC-1 from double-stranded cDNA generated from random-primed, reverse-transcribed total RNA from human monolayer-cultured chondrocytes. Under these conditions, RNA-PCR detected PC-1 as a product of the predicted ( $370 \mathrm{bp}$ ) length in osteosarcoma cells and hepatoma cells (Fig. 6, lanes 1 and 3) and in murine plasmacytoma (NS-1 cells) (Fig. $7 B$, lane 4 ). RNA-PCR verified PC-1 mRNA expression in human chondrocytes (Fig. $7 B$, lane 1 ). Chondrocytes cultured in the presence of $200 \mathrm{nM}$ dexamethasone (which can enhance PC-1 transcription in certain mouse plasmacytoma cells [34]) and the cartilage growth factor, TGF $\beta 1$ (Fig. $7 B$, lanes 2 and 3 ), were verified, in a qualitative manner, to also transcribe PC-1. In parallel, the detection of transcription of a housekeeping gene, the ribosomal protein L30 (44), by a single round of PCR, verified approximately equal loading of cDNA

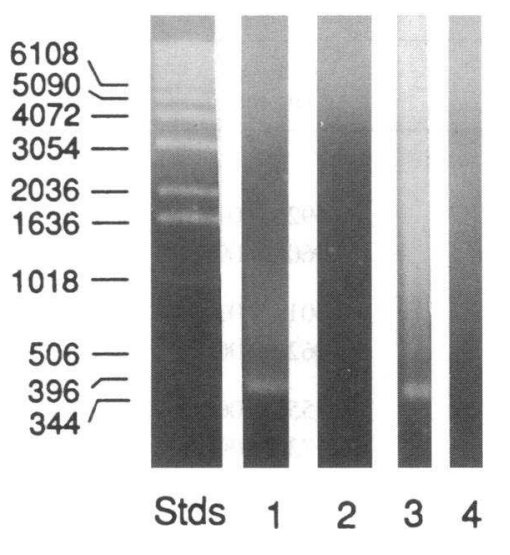

Figure 6. RNA-PCR detects PC-1 transcription in osteosarcoma cells and hepatoma cells. We used two rounds of PCR, with nested primers, to amplify PC-1 from doublestranded cDNA generated from randomprimed, reverse-transcribed total RNA ( 5 $\mu \mathrm{g})$, as described in Methods. The second round of PCR gave a product of the expected size (381 bp). Standards (RNA ladder) are indicated on the left. Lane 1 , U2OS cells; lane 2 , control for lane 1 (no template); lane 3, Hep G2 cells; lane 4, control for lane 3 (no template). 

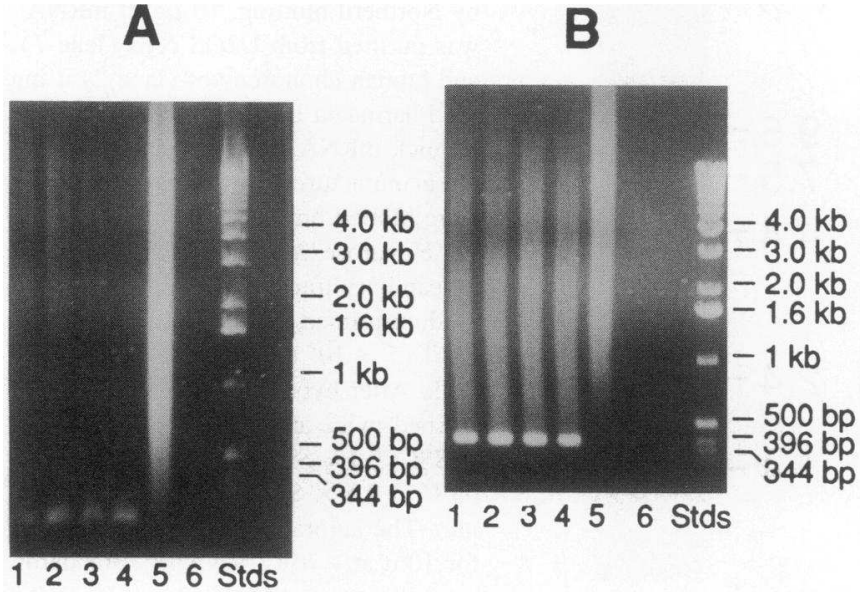

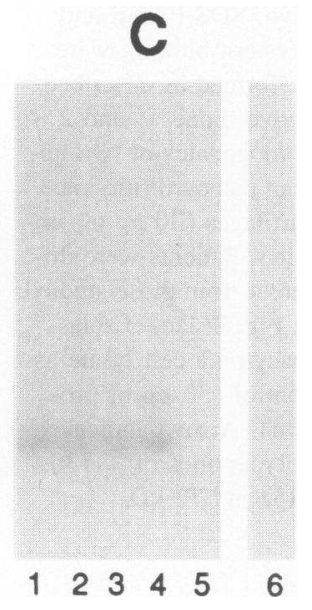

Figure 7. Qualitative demonstration of PC-1 transcription in chondrocytes and plasma cells by RNA-PCR. ( $A$ ) RNA-PCR for housekeeping gene L30 performed from $5 \mu \mathrm{g}$ of total RNA as described in Methods. Lane 1 , human chondrocytes, second passage; lane 2 , chondrocytes cultured in $100 \mu \mathrm{M}$ dexamethasone; lane 3 , chondrocytes cultured with recombinant TGF $\beta 1 \mu \mathrm{g} / \mathrm{ml}$; lane 4 , NS-1 cells; lane 5 , no template control, nonsense primers lane 6 , no template control for lane 1 . Lanes 1-4 yielded a PCR product of the expected size for L30 (196 bp). (B) RNA-PCR for PC-1. Lanes $1-4$ as in $A$. Lane 5, no template control; lane 6 , no sample. Lanes $1-4$ yielded a PCR product of the expected size ( $381 \mathrm{bp}$ ) for PC-1. $(C)$ Southern blotting verification of hybridization of PC-1 RNA-PCR product with ${ }^{32} \mathrm{P}$-labeled full-length PC-1 cDNA probe. Lanes $I-5$ as in $B$. Lane 6 contains L30 PCR product from $A$, lane 2 , as negative control.
(Fig. $7 A$ ). The specificity of PC-1 detection by RNA-PCR was confirmed by demonstrating that the 370-bp products of the PC-1 RNA-PCR reaction, but not the 160-bp products of the L30 RNA-PCR reaction, hybridized with a full-length human PC-1 cDNA probe (Fig. $7 C$ ).

Therefore, PC-1 was constitutively expressed as a low abundance mRNA by cultured osteosarcoma cells and articular chondrocytes.

Regulation of PC-1 expression in osteosarcoma cells by $T G F \beta$. The constitutively low expression of PC- 1 observed in cultured cells from bone and cartilage suggested the potential importance of identifying physiologically significant factors that could upregulate PC-1 expression. Recently, Oyajobi et al. (48) demonstrated that coculture (for $72 \mathrm{~h}$ ) with the bone and cartilage growth and repair factor TGF $\beta 1$ significantly increased NTPPPH activity in primary cultures of osteoblastlike cells from the trabecular bone of adult human femora. Thus, we first verified the functional significance of the PC1 expressed by human osteosarcoma cells by immunoprecipitation (Table I). We verified that antibodies to PC-1, but not preimmune IgG, or staph protein A-Sepharose alone immunoprecipitated NTPPPH ( 5 '-nucleotide phosphodiesterase I) activity from murine NS-1 plasmacytoma cell lysates. Under these conditions, anti-PC-1 precipitated enzyme activity from lysates of human osteosarcoma cells, at the same time depleting this activity from the lysates (Table I). Thus, PC1 was expressed in osteosarcoma cells in a functionally active form.

TGF $\beta 1$ significantly increased cellular NTPPPH activity in U2OS osteosarcoma cells (Table II), in association with the detection of de novo synthesized $\left[{ }^{35} \mathrm{~S}\right]$ methionine-labeled PC1 polypeptides (Fig. $8 A$ ). Analysis of PC-1 gene expression in osteosarcoma cells by RNA-PCR suggested a TGF $\beta$-induced increase in PC-1 mRNA (Fig. $8 \mathrm{~B}$ ). This was confirmed by noting upregulation of PC-1 mRNA $(3.8 \mathrm{~kb})$ by Northern blotting (Fig. 8, $C$ and $D$ ) where PC-1 mRNA could be detected easily in the TGF $\beta$-stimulated cells but not control cells using only $15 \mu \mathrm{g}$ of total RNA. Thus, TGF $\beta$ upregulated both PC-1 gene expression and 5'-nucleotide phosphodiesterase I/ NTPPPH in osteosarcoma cells.

Table I. Immunoprecipitation of 5'-Nucleotide Phosphodiesterase I Activity from Murine Plasmacytoma (NS-1) and Human Osteosarcoma Cells (U2OS) by Antibodies to PC-1

\begin{tabular}{|c|c|c|c|c|}
\hline Conditions & $\begin{array}{l}\text { NS-1 cells } \\
\text { OD } 405\end{array}$ & NS- 1 cells & $\begin{array}{l}\text { U2OS cells } \\
\text { OD } 405\end{array}$ & U2OS cells \\
\hline & & enzyme U/ml & & enzyme U/ml \\
\hline Sup/no IgG & $0.592 \pm 0.010$ & $7.74 \pm 0.14$ & $0.703 \pm 0.026$ & $9.2 \pm 0.34$ \\
\hline Beads/no IgG & $0.060 \pm 0.002$ & $0.78 \pm 0.02$ & $0.064 \pm 0.006$ & $0.84 \pm 0.08$ \\
\hline Sup/preimmune IgG & $0.601 \pm 0.028$ & $7.85 \pm 0.36$ & $0.701 \pm 0.016$ & $9.2 \pm 0.21$ \\
\hline Beads/preimmune IgG & $0.062 \pm 0.003$ & $0.82 \pm 0.04$ & $0.064 \pm 0.001$ & $0.84 \pm 0.03$ \\
\hline Sup/anti-PC-1 IgG & $0.555 \pm 0.005$ & $7.26 \pm 0.06$ & $0.435 \pm 0.065$ & $5.7 \pm 0.84$ \\
\hline Beads/anti-PC-1 IgG & $0.173 \pm 0.008$ & $2.27 \pm 0.11$ & $0.358 \pm 0.043$ & $4.7 \pm 0.55$ \\
\hline
\end{tabular}

Triton X-100 cell lysates ( $40 \mu \mathrm{g}$ protein in a total volume of $0.02 \mathrm{ml}$ ) were incubated in triplicate with $0.01 \mathrm{ml}$ of nonimmune rabbit $\mathrm{IgG}$, or the same volume of anti-PC-1 IgG, and with Staph protein A-Sepharose beads ( $0.05 \mathrm{ml}$ of a $50 \%$ suspension) as described in Methods. Sedimented, washed beads, and the remaining supernatant (Sup) were assayed for $5^{\prime}$-nucleotide phosphodiesterase I as described in Methods. Enzyme units are expressed in micromoles of substrate hydrolyzed per hour per sample. Values are representative of four separate experiments. 
Table II. TGF $\beta$ Increases 5'-Nucleotide Phosphodiesterase I in U2OS Osteosarcoma Cells

\begin{tabular}{llc}
\hline \multicolumn{1}{c}{ Conditions } & \multicolumn{1}{c}{ OD 405 } & $\begin{array}{c}\text { Enzyme U/50 } \mu \mathrm{g} \\
\text { cell protein }( \pm \mathrm{SD})\end{array}$ \\
\hline U2OS cells (control) & $0.332 \pm 0.01$ & $7.8 \pm 0.24$ \\
U2OS cells plus TGF $\beta$ & $0.395 \pm 0.01^{*}$ & $9.3 \pm 0.15^{*}$ \\
\hline
\end{tabular}

Confluent U2OS cells were incubated for $24 \mathrm{~h}$ (within a Falcon 3046 culture plate [Falcon Labware, Oxnard, CA] in $3 \mathrm{ml} \mathrm{McCoy's} \mathrm{5A} \mathrm{with}$ $15 \%$ FCS), as described above, with either no addition (control) or the presence of human recombinant TGF $\beta 1(1 \mathrm{ng} / \mathrm{ml})$. Cells were harvested and then Triton-lysed, and 5'-nucleotide phosphodiesterase I activity was measured in aliquots $(n=3)$ that contained $50 \mu \mathrm{g}$ of cellular protein, as described above. The results indicated were from cells sampled at the same passage as in the experiment outlined in Fig. 8, $A-D$ (results were similar in three other experiments). ${ }^{*} P<0.01$ for TGF $\beta$ relative to control

\section{Discussion}

NTPPPH activity is implicated in physiologic and pathologic skeletal and cartilage mineralization $(21,22)$. This study is the first to establish a molecular identity for an NTPPPH enzyme species in cells derived from human bone and cartilage. We hypothesized that, like certain other ectoenzyme genes (e.g., alkaline phosphatase), at least one NTPPPH might have a closely related identity in cells from liver, bone, and cartilage and in certain differentiated leukocytes. We demonstrated that expression of PC-1, an NTPPPH/5'-nucleotide phosphodiesterase I (previously detected in murine plasma cells [32, 34], human fibroblasts [47], and bovine hepatocytes [35]), is a property shared by human HepG2 hepatoma cells, chondrocytes, and osteoblast-like U2OS osteosarcoma cells (40).

We observed that human osteosarcoma cells, chondrocytes, hepatoma cells, and murine plasmacytoma cells expressed PC1 polypeptides as species of variable size (including those of $\sim 230-260,115-130,90$, and $60 \mathrm{kD}$ ). We also detected PC-1 expression not only in vitro but also in vivo (from homogenized human cartilage [Fig. 3]). Full-length PC-1 is a glycosylated transmembrane homodimer of $115-130 \mathrm{kD}(33,34)$. Incomplete reduction of the intracellular interchain disulfide bond in the relatively inaccessible transmembrane region of PC-1 (39) likely accounts for detection of some of the larger species, as in Figs. 1, 2, and $8 \mathrm{~A}$. Previous observations on COS cells transfected with PC-1, and on untransfected plasma cells, suggest that PC-1 polypeptides may also be expressed as soluble forms with lower molecular masses of 45-92 $\mathrm{kD}(37,39)$. Furthermore, the primary structure of PC-1 contains numerous potential proteolytic cleavage sites $(33,34,39)$. In this regard, the appearance of less than full-length cross-reactive species of PC-1 (including the 60-kD species) increases with time in storage in lysates of osteosarcoma cells and chondrocytes and in cells transfected with PC-1 cDNA (38), suggesting possible degradative events (data not shown). Thus, it will be important in further studies to define potential proteolytic processing and/ or alternative splicing of PC-1 in these tissues and to define the enzymatic properties of individual processed PC-1 polypeptides.

Interestingly, various soluble forms of 5 '-nucleotide phosphodiesterase I have been described in serum (49-51). Further-

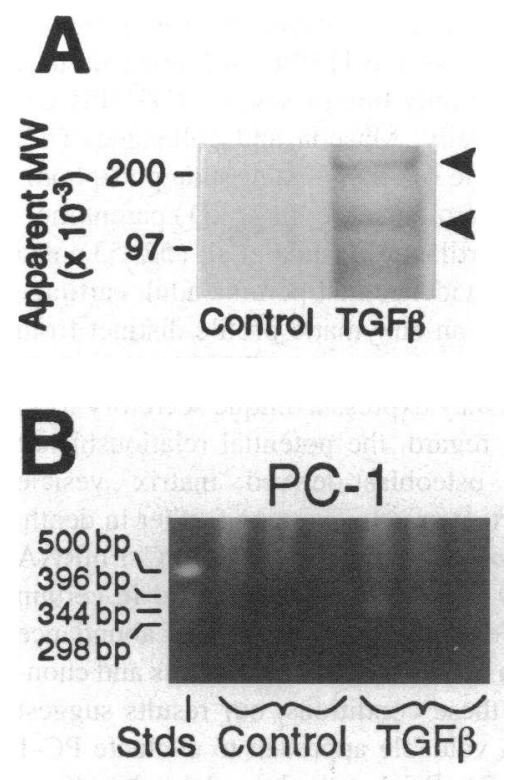

Figure 8. TGF $\beta$ upregulates PC-1 expression in osteosarcoma cells. All experiments were done using cells at the same passage as in Table II. (A) Human U2OS osteosarcoma cells $(\sim 0.5 \times$ $10^{6}$ cells) labeled with $\left[{ }^{35} \mathrm{~S}\right]$ methionine were left untreated in complete medium with $15 \%$ FCS or treated in the same medium with added human recombinant TGF $\beta 1$ ( $1 \mathrm{ng} / \mathrm{ml}$ ) for $24 \mathrm{~h}$, and cell lysates were then immunoprecipated with anti-PC-1 antibodies and analyzed by SDS/ PAGE and enhanced autoradiography as described in Methods. Arrows indicate precipitated PC-1 polypeptides of $\sim 130$ and $260 \mathrm{kD}$ in TGF $\beta$-treated cells. Control precipitations with nonimmune sera were negative (not shown). (B) Total RNA (5 $\mu \mathrm{g}$ ) from the untreated and TGF $\beta$-treated osteosarcoma cells was isolated at $24 \mathrm{~h}$, reverse-transcribed, and analyzed for PC-1 and housekeeping gene (L30) mRNA by nested RNA-PCR as described above. In the

\section{(Kb)}

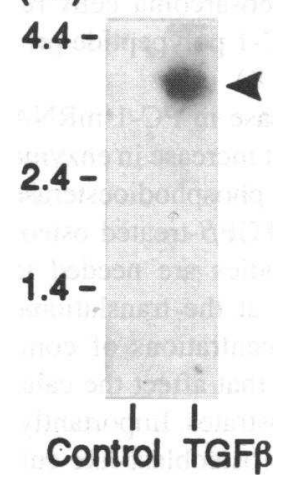

D

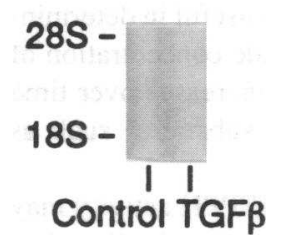
electrophoresis gels indicated, $20 \%$ of each final PCR product was serially diluted twice at 1:1 (proceeding left to right on gels ). More PC-1 mRNA (but equivalent amounts of L30 mRNA) was detectable in TGF $\beta$-treated cells by these methods. (C) Total RNA ( 15 $\mu \mathrm{g})$ from the untreated and TGF $\beta$-treated osteosarcoma cells was analyzed by Northern blotting using randomprimed ${ }^{32} \mathrm{P}$-labeled human recombinant PC-1 as described above. The autoradiograph was exposed for $4 \mathrm{~d}$ at $-70^{\circ} \mathrm{C}$. RNA size standards are indicated. Arrowhead, 3.8 kb PC-1 mRNA. (D) Ethidium bromidestained gel from $C$ above as it appeared before transfer. 
more, erythrocytes express a unique NTPPPH selective for inosine triphosphate (1). Thus, genes other than PC-1 may encode 5 '-nucleotide phosphodiesterase I/NTPPPH in human tissues. In this regard, PC-1 may be only one of several NTPPPH enzymes in cartilage. Specifically, Masuda and colleagues (52, 53 ) recently purified a soluble $61-\mathrm{kD} 5^{\prime}$-nucleotide phosphodiesterase I/NTPPPH derived from a larger (127 kD) parent molecule in porcine articular cartilage. Masuda et al. $(52,53)$ also have provided preliminary evidence that porcine adult cartilage matrix vesicle NTPPPH has an enzymatic profile distinct from that of cartilage chondrocyte membrane NTPPPH. Thus, it is possible that chondrocytes may express a unique secretory form of NTPPPH (53). In this regard, the potential relationship of PC-1 to cartilage and osteoblast-derived matrix vesicle NTPPPH will be an important area to examine further in depth.

Regulation of PC-1 expression. The amount of PC-1 mRNA is constitutively quite low in human fibroblasts and in certain other tissues $(33,47)$. We similarly observed low abundance PC-1 mRNA expression in resting osteosarcoma cells and chondrocytes (Fig. 5). Under these conditions, our results suggest that RNA-PCR may be a valuable approach to evaluate PC-1 transcription (Figs. 6 and 7). PC-1 was also a low abundance protein product in cultured chondrocytes and osteosarcoma cells. In this regard, plasmacytoma cells (Fig. 1, lane 3), which have high PC-1 specific activity, similarly have a low abundance of PC-1 protein, i.e., only $\sim 10 \mu \mathrm{g}$ of PC-1 can be purified per $100 \mathrm{~g}$ of plasmacytoma tumors (34).

TGF $\beta 1$, a growth and repair factor present in bone and cartilage matrix $(48,54)$, has recently been observed to significantly increase NTPPPH activity in primary cultures of osteoblast-like cells from human femoral trabecular bone, an effect attenuated by inhibitors of transcription and of translation (48). We noted that TGF $\beta 1$ also induced upregulation of 5 '-nucleotide phosphodiesterase I/NTPPPH in osteoblast-like U2OS osteosarcoma cells (Table II) and we demonstrated that the PC1 expressed by osteosarcoma cells was enzymatically functional (Table I). We also demonstrated that osteosarcoma cells responded to TGF $\beta 1$ by clearly increasing PC- 1 polypeptide production and PC-1 mRNA expression (Fig. 8).

The contrast between the marked increase in PC-1 mRNA transcripts (Fig. 8) and the relatively modest increase in enzyme activity $\left(\sim 20 \%\right.$ increase in $5^{\prime}$-nucleotide phosphodioesterase I activity measured over $1 \mathrm{~h}$, Table II) in TGF $\beta$-treated osteosarcoma cells was unexpected. Future studies are needed to determine whether PC-1 also is regulated at the translational level or whether TGF $\beta$ can alter the concentrations of compounds (e.g., nucleoside monophosphates) that affect the catalytic rate of NTPPPH $(6,9)$ for different substrates. Importantly, the effect of TGF $\beta$ on NTPPPH in primary osteoblast-like cultures is characterized by a progressive rise (that reaches a twoto threefold increase) in extracellular PPi generation in the presence of added extracellular ATP over $72 \mathrm{~h}$ in culture (48). The sustained elevation of PPi concentration under these conditions may be partially mediated by an inhibitory effect on PPi-splitting alkaline phosphatase activity (48). The development of a specific immunoassay for PC-1 should prove useful in determining whether small increases in the polypeptide concentration of PC-1 in cells are sufficient to induce large increases over time in the degradation of individual NTPPPH substrates such as ATP.

Interestingly, the effects of TGF $\beta$ on NTPPPH activity may be tissue specific. Specifically, human dermal fibroblast
NTPPPH activity (which appears largely attributable to PC-1 [47]) is not upregulated by TGF $\beta$ (48). In contrast, Rosenthal et al. (55) have shown that TGF $\beta$ affects a modest $(\sim 10 \%)$ but significant increase in plasma membrane NTPPPH in porcine articular cartilage chondrocytes. We addressed only qualitative expression of PC-1 mRNA in chondrocytes, detecting expression by RNA-PCR after TGF $\beta$ stimulation (Fig. 7). More detailed assessment of the effects of TGF $\beta$ and other growth and repair factors on PC-1 expression in fibroblasts and chondrocytes is an important area for further study.

NTPPPH/PC-1 is expressed as an ectoenzyme on not only the plasma membrane but also in the rough endoplasmic reticu$\operatorname{lum}(31,37)$. Importantly, upregulation of PC-1 expression by cDNA transfection markedly increases not only extracellular PPi generation but also intracellular PPi generation (38). Furthermore, the latter effect does not require supplementation with exogenous ATP (38). Thus, it will be important in future studies to test the hypothesis that transcriptional upregulation of PC- 1 by TGF $\beta$ and other bone and cartilage growth factors may be one mechanism by which cells specialized for mineralization modulate rapid increases in PPi generation.

In conclusion, the identification of PC-1 as an NTPPPH expressed by cells derived from cartilage and bone may provide a novel molecular tool to further understand the role of NTPPPH expression in both physiologic and pathologic bone and cartilage mineralization.

\section{Acknowledgments}

We gratefully acknowledge Dr. Martin Lotz (UCSD) for helpful suggestions and additional assistance via the preparation and isolation of human chondrocytes.

This study was supported by Merit Review Awards from the Department of Veterans Affairs, National Institutes of Health grant DK-36702, the Anti-Cancer Council of Victoria, Australia, the Stein Institute for Research on Aging, and a California Medical Education and Research Foundation grant to Raymond Huang, who completed this work to satisfy requirements for his UCSD School of Medicine Independent Study Project thesis.

\section{References}

1. Chern, C. J., A. B. McDonald, and A. J. Morris. 1969. Purification and properties of nucleoside triphosphate pyrophosphohydrolase from red cells of the rabbit. J. Biol. Chem. 244:5489-5495.

2. Wang, J. K., and A. J. Morris. 1974. The distribution of nucleoside triphosphate pyrophosphohydrolase in the tissues of the rabbit. Arch. Biochem. Biophys. 161:118-124.

3. Haugen, H. F., and S. Skrede. 1977. Nucleotide pyrophosphatase and phosphodiesterase. I. Organ distribution and activities in biological fluids. Clin. Chem. 23:1531-1538.

4. Yano, T., K. Horie, R. Kanamoto, H. Kitagawa, I. Funakoshi, and I. Yamashina. 1987. Immunoaffinity purification and characterization of nucleotide pyrophosphatase from human placenta. Biochem. Biophys. Res. Commun. 147:10611069.

5. Che, M. X., T. Nishida, Z. Gatmaitan, and I. M. Arias. 1992. A nucleoside transporter is functionally linked to ectonucleotidases in rat liver canalicular membrane. J. Biol. Chém. 267:9684-9689.

6. Dornand, J., J. Bonnafous, J. Favero, and J. C. Mani. 1982. Ecto-5' nucleotidase and adenosine deaminase activities of lymphoid cells. Biochem. Med. 28:144-150.

7. Andree, T., W. Gutensohn, and U. Kummer. 1987. Is ecto-5'-nucleotidase essential for stimulation of human lymphocytes? Evidence against a role of the enzyme as mitogenic lectin receptor. Immunobiology. 175:214-219.

8. Balazovich, K. J., and L. A. Boxer. 1990. Extracellular adenosine nucleotides stimulate protein kinase $\mathrm{C}$ activity and human neutrophil activation. $J$. Immunol. 144:631-637.

9. Muniz, O., J. P. Pelletier, J. Martel-Pelletier, S. Morales, and D. Howell. 
1984. NTP pyrophosphohydrolase in human chondrocalcinotic and osteoarthritic cartilage. I. Some biochemical characteristics. Arthritis Rheum. 27:186-192.

10. Howell, D., J. Martel-Pelletier, J. P. Pelletier, S. Morales, and O. Muniz. 1984. NTP pyrophosphohydrolase in human chondrocalcinotic and osteoarthritic cartilage. II. Further studies on histologic and subcellular distribution. Arthritis Rheum. 27:193-199.

11. Siegel, S. A., C. F. Hummel, and R. P. Carty. 1983. The role of nucleoside triphosphate pyrophosphohydrolase in in vitro nucleoside triphosphate-dependen matrix vesicle calcification. J. Biol. Chem. 258:8601-8607.

12. Hsu, H. H. T. 1983. Purification and partial characterization of ATP pyrophosphohydrolase from fetal bovine epiphyseal cartilage. J. Biol. Chem. 258:3463-3468.

13. Caswell, A. M., S. Y. Ali, R. G. Russell. 1987. Nucleoside triphosphate pyrophosphatase of rabbit matrix vesicles, a mechanism for the generation of inorganic pyrophosphate in epiphyseal cartilage. Biochim. Biophys. Acta 924:276-283.

14. Watkins, E. L., J. V. Stillo, and R. E. Wuthier. 1980. Subcellular fractionation of epiphyseal cartilage isolation of matrix vesicles and profiles of enzymes phospholipids, calcium and phosphate. Biochim. Biophys. Acta. 631:289-304.

15. Yu Wu, L. N., B. R. Genge, and R. E. Wuthier. 1991. Association between proteoglycans and matrix vesicles in the extracellular matrix of growth plate cartilage. J. Biol. Chem. 266:1187-1194.

16. Rachow, J. W., L. M. Ryan, D. J. McCarty, and P. C. Halverson. 1988 Synovial fluid inorganic pyrophosphate concentration and nucleotide pyrophosphohydrolase activity in basic calcium phosphate deposition arthropathy and Milwaukee shoulder syndrome. Arthritis Rheum. 31:408-413.

17. Tenenbaum, J., O. Muniz, H. R. Schumacher, A. E. Good, and D. S Howell. 1981. Comparison of phosphohydrolase activities from articular cartilage in calcium pyrophosphate deposition disease and primary osteoarthritis. Arthritis Rheum. 24:492-500.

18. Ryan, L. M., R. L. Wortmann, B. Karas, M. P. Lynch, and D. J. McCarty 1986. Pyrophosphohydrolase activity and inorganic pyrophosphate content of cultured human skin fibroblasts. Elevated levels in some patients with calcium pyrophosphate dihydrate deposition disease. J. Clin. Invest. 77:1689-1693.

19. Pattrick, M., E. Hamilton, J. Hornby, and M. Doherty. 1991. Synovial fluid pyrophosphate and nucleoside triphosphate pyrophosphatase: comparison between normal and disease and between inflamed and non-inflamed joints. Ann. Rheum. Dis. 50:214-218.

20. Doherty, M., E. Hamilton, J. Henderson, H. Mirsra, and J. Dixey. 1991 Familial chrondrocalcinosis due to calcium pyrophosphate dihydrate crystal deposition in English families. Br. J. Rheum. 30:10-15.

21. Anderson, H. C. 1988. Mechanisms of pathologic calcification. Rheum. Dis. Clin. North Am. 14:303-319.

22. Derfus, B. A., J. W. Rachow, N. S. Mandel, A. L. Boskey, M. Buday, V. M. Kushnaryov, and L. M. Ryan. 1992. Articular cartilage vesicles generate calcium pyrophosphate dihydrate-like crystals in vitro. Arthritis Rheum. 35:231 240.

23. Ryan, L. M., J. W. Rachow, and D. J. McCarty. 1991. Synovial fluid ATP: a potential substrate for the production of inorganic pyrophosphate. $J$. Rheumatol. 18:716-720.

24. Ryan, L. M., I. V. Kurup, B. A. Derfus, and V. M. Kushnaryov. 1992 ATP-induced chondrocalcinosis. Arthritis Rheum. 35:1520-1525.

25. Fukui, S., H. Yoshida, and I. Yamashina. 1981. Sulfohydrolytic degradation of 3 '-phosphoadenosine 5'-phosphosulfate (PAPS) and adenosine 5'-phosphosulfate (APS) by enzymes of a nucleotide pyrophosphatase nature. J. Biochem 90:1537-1540

26. Ryan, L. M., R. L. Wortmann, B. Karas, and D. J. McCarty. 1984. Cartilage nucleoside triphosphate (NTP) pyrophosphohydrolase. I. Identification as an ectoenzyme. Arthritis Rheum. 27:404-409.

27. Caswell, A. M., and R. G. G. Russell. 1985. Identification of ecto-nucleoside triphosphate pyrophosphatase in human articular chondrocytes in monolayer culture. Biochim. Biophys. Acta. 847:40-47.

28. Rambaldi, A., M. Terao, S. Bettoni, M. L. Tini, R. Bassan, T. Barbui, and E. Garattini. 1990. Expression of leukocyte alkaline phosphatase gene in norma and leukemic cells: regulation of the transcript by granulocyte colony-stimulating factor. Blood. 76:2565-2571.

29. Sun, A. S., and M. Renaud. 1989. Enhancement of 5'-nucleotidase activity of human leukemic cells after fractionation: implications for cancer and aging. Mutat. Res. 219:295-302.

30. van Driel, I. R., A. F. Wilks, G. A. Pietersz, and J. W. Goding. 1985 Murine plasma cell membrane antigen PC-1: molecular cloning of cDNA and analysis of expression. Proc. Natl. Acad. Sci. USA. 82:8619-8623.

31. Hickman, S., Y. P. Wong-Yip, N. Rebbe, and J. M. Greco. 1985. Formation of lipid-linked oligosaccharides by MOPC 315 plasmacytoma cells. Decreased synthesis by a nonsecretory variant. J. Biol. Chem. 260:6096-6106.

32. van Driel, I. R., and J. Goding. 1987. Plasma cell membrane glycoprotein PC-1. Primary structure deduced from cDNA clones. J. Biol. Chem. 262:48824887.
33. Buckley, M. F., K. A. Loveland, W. J. McKinstry, M. Garson, and J. W. Goding. 1990. Plasma cell membrane glycoprotein PC-1. cDNA cloning of the human molecule, amino acid sequence, and chromosomal location. J. Biol. Chem. 265:17506-17511.

34. Rebbe, N., B. Tong, E. M. Finley, and S. Hickman. 1991. Identification of nucleotide pyrophosphatase/alkaline phosphodiesterase I activity associated with the mouse plasma cell differentiation antigen PC-1. Proc. Natl. Acad. Sci. USA. 88:5192-5196.

35. Oda, Y., M. D. Kuo, S. S. Huang, and J. S. Huang. 1991. The plasma cell membrane glycoprotein kinase stimulated by acidic fibroblast growth factor. J. Biol. Chem. 266:16791-16795.

36. Harahap, A. R., and J. W. Goding. 1988. Distribution of the murine plasma cell antigen PC-1 in non-lymphoid tissues. J. Immunol. 141:2317-2320.

37. Rebbe, N. F., B. D. Tong, and S. Hickman. 1993. Expression of nucleotide pyrophosphatase and alkaline phosphodiesterase I activities of PC-1, the murine plasma cell antigen. Mol. Immunol. 30:87-93.

38. Terkeltaub, R., M. Rosenbach, F. Fong, and J. Goding. 1994. A causal link between nucleotide pyrophosphohydrolase overactivity and increased intracellular PPi generation is demonstrated by transfection of cultured fibroblasts and osteoblasts with PC-1 (plasma cell membrane glycoprotein-1): relevance to CPPD deposition disease. Arthritis Rheum. In press.

39. Belli, S. I., I. R. van Driel, and J. W. Goding. 1993. Identification and characterization of a soluble form of the plasma cell membrane glycoprotein PC1 (5' nucleotide phosphodiesterase). Eur. J. Biochem. 217:421-428.

40. Kanzaki, S., S. Hilliker, D. Baylink, and S. Mohan. 1994. Evidence that human bone cells in culture produce insulin-like growth factor-binding protein-4 and -5 proteases. Endocrinology. 134:383-392.

41. Villiger, P. M., R. Terkeltaub, and M. Lotz. 1992. Monocyte chemoattractant protein-1 (MCP-1) expression in human articular cartilage. Induction by peptide regulatory factors and differential effects of dexamethasone and retinoic acid. J. Clin. Invest. 90:488-496.

42. Lotz, M., R. Terkeltaub, and P. M. Villiger. 1992. Chondrocytes and joint inflammation: expression of IL-8 in response to peptide regulatory factors and proinflammatory agents. J. Immunol. 148:466-473.

43. Terkeltaub, R., C. A. Dyer, J. Martin, and L. K. Curtiss. 1991. Apolipoprotein (Apo) $\mathrm{E}$ inhibits the capacity of monosodium urate crystals to stimulate neutrophils. Characterization of intraarticular apo $E$ and demonstration of apo $E$ binding to urate crystals in vivo. J. Clin. Invest. 87:20-26.

44. Nakanishi, O., M. Oyanagi, Y. Kuwano, T. Tanaka, T. Nakayama, H. Mitsui, Y. Nabeshima, and K. Ogata. 1985. Molecular cloning and nucleotide sequence of cDNAs specific for rat liver ribosomal proteins S17 and L30. Gene (Amst.) 35:289-296.

45. Culp, J. S., H. J. Blytt, M. Hermodson, and L. G. Butler. 1985. Amino acid sequence of active site peptide of bovine intestinal 5 '-nucleotide phosphodiesterase and identification of the active site residue as threonine. J. Biol. Chem. 260:8320-8324

46. Skinner, M. A. 1991. Murine plasma cell antigen PC-1 has a region homologous to the active site of bovine intestinal 5 '-nucleotide phosphodiesterase I (EC 3.1.4.1). Nucleic Acids Res. 19:6049.

47. Funakoshi, I., H. Kato, K. Horie, T. Yano, Y. Hori, H. Kobayashi, T. Inoue, H. Suzuki, S. Fukui, M. Tsukahara, et al. 1992. Molecular cloning of cDNAs for human fibroblast nucleotide pyrophosphatase. Arch. Biochem. Biophys. 295:180-187.

48. Oyajobi, B. O., A. S. Caswell, and R. G. Russell. 1994. Transforming growth factor $\beta$ increases ecto-nucleoside triphosphate pyrophosphatase activity of human bone-derived cells. J. Bone Miner. Res. 9:99-109.

49. Luthje, J., and A. Ogilvie. 1987. 5'-Nucleotide phosphodiesterase isoenzymes in human serum: quantitative measurement and some biochemical properties. Clin. Chim. Acta. 164:275-284.

50. Luthje, J., S. Pickert, A. Ogilvie, E. Horneman, W. Siegfried, A. Waldherr, and W. Domschke. 1988. Levels of 5'-nucleotide phosphodiesterase isoenzymes in normal and pathological sera. Clin. Chim. Acta. 177:131-140.

51. Fujiyama, S., K. Tsude, M. Sakai, and T. Sato. 1990. 5'-Nucleotide phosphodiesterase isozyme- $\mathrm{V}$ in hepatocellular carcinoma and other liver diseases. Hepato-Gastroenterology. 37:469-473

52. Masuda, I., A. L. Haas, L. M. Ryan, and D. J. McCarty. 1992. Purification and characterization of cartilage nucleoside triphosphate pyrophosphohydrolase. Arthritis Rheum. 35:S216a. (Abstr.)

53. Masuda, H. I., J. Hamada, B. A. Derfus, A. L. Haas, L. M. Ryan, and D. J. McCarty. 1993. An unique nucleoside triphosphate pyrophosphohydrolase in chondrocyte vesicles. Arthritis Rheum. 36:S89a. (Abstr.)

54. Seyedin, S. E., A. Y. Thompson, H. Bentz, D. M. Rosen, J. M. McPherson, A. Conti, N. R. Siegel, J. R. Gallupi, and K. A. Piez. 1986. Cartilage-inducing factor-A: apparent identity to transforming growth factor- $\beta$. J. Biol. Chem. 261:5693-5695

55. Rosenthal, A. K., H. S. Cheung, and L. M. Ryan. 1991. Transforming growth factor beta 1 stimulates inorganic pyrophosphate elaboration by porcine cartilage. Arthritis Rheum. 34:904-911. 